Discourse and Communication for Sustainable Education, vol. 7, no. 1, pp. 5-22, 2016

\title{
Higher Education Students' Perceptions of Environmental Issues and Media Coverage
}

\author{
Tuula Keinonen \\ University of Eastern Finland, Finland \\ Irmeli Palmberg \\ Åbo Academi Vasa, Finland \\ Jari Kukkonen \\ University of Eastern Finland, Finland \\ Eija Yli-Panula \\ University of Turku, Finland \\ Christel Persson \\ Högskolan Kristianstad, Sweden \\ Rytis Vilkonis \\ Siauliai University, Lithuania
}

\begin{abstract}
This study aims to find higher education students' perceptions about environmental issues and how the perceptions are related to perceptions of media coverage. This study investigates higher education students' perceptions of the seriousness of environmental issues and their relation to perceptions of media coverage. Higher education students perceived a global problem, lack of clean water, as most serious environmental problem. Media has had an effect on students' perceptions on environmental issues: when students perceived the problem as serious they also perceived the information in media concerning it appropriate. Students perceived that the media underestimate and obscure some environmental problems such as biological diversity and global warming. It was concluded that higher education educators need more knowledge of students', future decision makers' concerns and perceptions about environmental issues to develop more effective teaching practices in higher education. Through education environmental issues literacy, which is a precursor for engaged protection of the environment, can be fostered. This study offers some insights into higher education students' perceptions of the media's role in environmental issues.
\end{abstract}

Keywords: higher education, perceptions, environmental issues, media coverage 
Higher education students will need to make complex policy decisions about environmental issues from an informed perspective. Therefore, higher education faculty needs more knowledge about students' concerns and perceptions of environmental issues. The relationships between environmental attitudes, sensitivity, concern, knowledge, action and participation has been a topic of much research and debate in the field of environmental education (e.g., Dunlap \& Van Liere 1978; Bogner \& Wilhelm 1996; Campbell Bradley et al., 1999; Bogner \& Wiseman 2002; Esa 2009; Johnson \& Manoli 2011). Scholars have agreed that some type of relationship between attitudes and behaviour exists. Perception is closely related to attitude, thus understanding students' perceptions could lead to more effective teaching practices in higher education and foster greater levels of environmental issues literacy, which is a precursor for engagement in protection of the environment.

Research on concerns about environmental issues has mostly focused on perceptions of climate change held by elementary and secondary school students (Andersson \& Wallin 2000; Boyes \& Stanisstreet 1993; Salìte \& Klepere, 2003; Shepardson et al., 2011; Iliško, Skrinda, Mičule, 2014) and the general public (TNS Opinion \& Social, 2011; Smith \& Joffe, 2012). Some studies have involved university students and found that young adults believe that climate change is real (e.g. Feldman et al., 2010; Wachholz et al., 2014).

Most Europeans agree that environmental problems have a direct effect on their daily lives, for example, by $76 \%$ of Finnish, $60 \%$ of Swedish and $83 \%$ of Lithuanian respondents in a European survey (TNS Opinion \& Social, 2011). Environmental issues that were the primary concerns of Europeans were related to the direct impacts of human activity on the environment at the global level: man-made disasters, water and air pollution, climate change, chemicals used in everyday products, resource depletion, waste, natural disasters and agricultural pollution (TNS Opinion \& Social, 2011). The lowest levels of concern were given to noise and urban pollution, transport and genetically modified products and the clearest change from 2007 to 2012 was that climate change was considered a far less important issue (TNS Opinion \& Social, 2011). Finnish university students perceived climate change and the lack of clean water as the most important environmental problems, followed by decreasing biodiversity; the least important was malaria (Kukkonen et al., 2012).

Europeans think that they can play a role in protecting the environment in their countries, with larger agreement in Sweden than Finland or Lithuania (TNS Opinion \& Social, 2011). More than 9 of 10 respondents believed that big polluters are responsible for protecting the environment, less in Finland than Sweden and Lithuania. A majority of respondents believed that decisions concerning environmental protection should be made at a European Union-wide level, whereas about one-third stated that decisions should be taken by national governments; this trend was stronger in Sweden and Lithuania than in Finland. (TNS Opinion \& Social, 2011.)

The media influence public perceptions. Among European residents, $60 \%$ reported themselves to be well informed about environmental issues (TNS Opinion \& Social, 2011). However, Europeans felt that they lacked information about the health impact of everyday products, genetic modification, agricultural and water pollution, natural resources depletion, biodiversity loss, man-made disasters, increasing waste and air pollution and climate change (TNS Opinion \& Social, 2011). In the United Kingdom, respondents' first thoughts mirrored visual images used by the British press to depict global warming (Smith \& Joffe, 2012). In a high-threat condition, both high- and low- 
efficacy messages can result in positive attitudes and behavioural changes, while in a low-threat condition, low-efficacy messages can lead to negative changes in attitudes and behavioural intentions (Sarrina Li, 2014); therefore, as a momentous issue, global warming can easily have evoked threatening feelings among college students.

Riffe and Hrach (2009) studied participants' perceptions of environmental risk where they live and of the information sufficiency of newspaper and television news exposure. Attention to environmental news in both types of media made separate and significant contributions to perceived risk and information sufficiency beyond that from general exposure and the control variables (Riffe \& Hrach, 2009). A sense of personal responsibility for global warming served as an important cause of respondents' subjective risk assessments of global warming: those who felt responsible for global warming were more concerned about its risks (Kellstedt et al., 2008). Informedness was positively associated with concern for all environmental issues; for example, as self-reported informedness on genetically modified organisms increased, so, too, did the level of reported concern for genetically modified organisms (Kellstedt et al., 2008).

This study investigates higher education students' perceptions of the seriousness of environmental issues and their relation to perceptions of media coverage.

\section{Media Coverage of Environmental Issues}

The communication of sustainability science to public audiences typically falls short as journalists, who are primarily good storytellers, not fact-finding scientists, compromise the accuracy and credibility of scientific information for entertainment value (Frank, 2014). There is a strong relationship between coverage of environmental issues by news organizations and individual-level knowledge and attitudes about this subject matter (Holbert et al., 2003). Riffe et al. (2007) studied how well newspapers and television cover different dimensions of environmental problems: causes, solutions, costs, victims and responsibility. Newspapers were rated as providing better coverage than local television news for solutions and costs to remedy environmental problems (Riffe et al., 2007.) Coverage of environmental problems has also been explored in the Estonian and Latvian press (Gooch, 1995): the majority of the articles were concerned with environmental issues concentrated in a few places within these countries, and international issues were localized to nearby European countries. A greater lack of environmental reporting in the press has been documented in Kyrgyzstan and Kazakhstan (Freedman, 2011).

Climate change has dominated the environmental news. In particular, climate change coverage in the British press has contributed to creating a public sphere that is truly yet modestly international in character, making political intervention that much more difficult (Gavin, 2009). Since the 1990s, the amount of media coverage of climate change has continued to increase and reached a high-water mark in 2006 and 2007 in 50 newspapers across 20 countries (Boykoff, 2009). In Australia, media coverage of climate change has increased exponentially since 2003 (Speck, 2010). Canadians are also reading more about climate change in their national print news but in a reporting style that is proportionately more skewed towards everyday political and business issues and isolated from discussions of science and direct impacts (Young \& Dugas, 2011). In America, the average person learns from the media controllers that global warming is controversial and possibly not related to human actions or that mass media coverage of climate change is deficient (Dispensa \& Brulle, 2003; Antilla, 2005; Boykoff \& Boykoff, 2007). 
Finnish press coverage in the context of climate change from 1990 to 2009 show a sharp increase since 2006 spurred by many intertwined factors, including both social and ecological issues on the global and national levels (Lyytimäki \& Tapio, 2009; Lyytimäki, 2011). Petersen (2007) found that 'although limits of growth was one prominent theme in 1992 in Danish television it was entirely absent in 2002, whilst coverage of criticism of the high cost and irrational priorities in environmental politics made an appearance.' Contrary to the discourse of ecological modernisation and sustainability, the issue of population growth was framed as an important environmental problem (Petersen, 2007).

\section{Methodology}

This study seeks to identify higher education students' perceptions of environmental issues and their relation to perceptions of media coverage. The following research questions guided the study:

What are students' perceptions about the seriousness of the environmental issues?

How, in students' opinions, do media address different environmental issues?

How do perceptions of the seriousness of environmental problems relate to media coverage?

\section{Participants and data collection}

Participants consisted of 429 students from three countries: Finland $(\mathrm{n}=307)$, Lithuania $(\mathrm{n}=59)$ and Sweden $(\mathrm{n}=63)$. The majority of students were teacher students ( $71 \%$ of the whole sample), while other majors include the social sciences, engineering and forest sciences. Seventy-five per cent of participants were female.

Data were collected through an Internet-based or paper questionnaire containing a total of 21 multiple-choice and open-ended questions. The English-language questionnaire developed by the researchers was translated into three languages (Swedish, Finnish and Lithuanian). Data were collected from three Finnish universities, one Swedish university and one Lithuanian university. Data collection took place in August 2011-January 2012. In this paper, the findings related to six multiple-choice questions are reported (see Appendix 1). The themes of the questions are the influence of environmental issues on daily life, the most serious environmental issues, the most and least emphasised environmental issues in the media, perceptions of environmental problems and their solutions and understanding of the greenhouse effect.

\section{Data analysis}

Data analysis focused on rankings of the importance of environmental problems to students' daily lives, the most serious environmental issues as perceived by the students and the media coverage of these environmental issues experienced by the students. The analysis also dealt with the ranking of the statements related to environmental problems and the greenhouse effect. The chi-square test was used because of the nature of the distribution of variables. The scheme for coding the open-ended answers was data based, developed by one research institute and refined by the others. 


\section{Context of the Study: An Overview of Media Coverage During the Data Collection Period}

In Finland, most of the environmental news during the study period concerned climate change, global warming and air pollution. Examples from short stories include ways to decrease the amount of greenhouse gases, such as to canalising forests in northern bogs and switching from coal to natural gas.

The impacts of greenhouse gases also received coverage. For example, newspapers published opinion pieces on methane and its impacts on environment. These statements were partly wrong, and the Climate Knowledge website (https://ilmastotieto.wordpress. com/artikkelit/) corrected some misconceptions about methane. The warming of the Earth was reported on frequently, the melting of the glaciers and the consequent rise of the sea level were emphasised. In Sweden, climate change was also reported on: economic research showed that environmental taxes could be effective at influencing demand for different fuels with different levels of carbon emissions in order to achieve political environmental targets. Air pollution also received coverage as the amount of carbon dioxide in the atmosphere had increased to the highest level in 800,000 years. The Durban climate change conference was reported on in Sweden. The conference produced a promised schedule for creating a new international climate agreement binding for all parties.

The new sulphur directive reduced the sulphur content of ship fuels, raising fears of rising investment costs and driving exports away from the Baltic Sea. During the study period, it became known that sulphur emitted to the Baltic Sea from a Russian fertilizer factory's gypsum waste had made the Gulf of Finland eutrophic. Water pollution was also reported in the Lithuania Delfi and in newspapers. Stories included an accident in a Lithuanian river, ship crashes off New Zealand and Africa, water pollution in the Baltic Sea and chemical guns in the Black Sea.

In Sweden, international rules to limit cod fisheries in the Baltic Sea were discussed. In 2011, the EU Council of Ministers decided to halve the cod fishery in the Kattegat while reducing the cod fishing fleet in the North Sea by a quarter. The media also reported on La Niña and El Niño as a very powerful storm swept across Australia, and huge amounts of rain fell in a short time, for which the mostly explanation was La Niña weather phenomenon.

One newspaper reported on a decision regarding Vaasa administrative law in Finland: according to it, a forest company must clean silt from its waste reservoirs within five years. Additionally, chrome and sulphur emissions from the steel factory were suspected of causing malformations in children born near the factory. Twenty employees of another company faced charges in an environmental criminal case of emitting liquid waste into nature and rain water in the sewer. In addition, the company had delivered fat waste to be handled at places other than legal sites. The problems of cleaning sewage from a mining company were discussed. The mine had already emitted uncleansed sewage into surrounding waterways, and police announced that they had launched an investigation into the company's actions. The problems of controlling environmental hazards were raised.

Challenges in food production related to climate change were also reported in Finland. The supply of farmland, water and energy was becoming less because of climate change, and seas were already overfished. It has been speculated that the riots of the 
Arab Spring were motivated by international increases in food prices. The preference for organic food has increased because of greater attention to the healthiness of food. The total evaluation of the food system was pointed out from the viewpoint of environmental impacts, while ecological impacts and locally produced food were also discussed in the Sweden and Lithuanian press.

The 2011 earthquake that hit Japan caused a devastating tsunami that knocked out the cooling system of the nuclear power station in Fukushima Daiichi. Three sharp explosions led to an extensive release of radioactivity, most of which ended up in the ocean east of Japan. The spread of pollutants not only from factories and farms but also from food, clothing, toys, cosmetics, hygiene products and electronics were debated extensively in Sweden. Chemicals identifying as needing immediate attention were brominated flame retardants, phthalates, antibacterials, drugs and per fluorinated substances.

\section{Research Results}

Students were first asked to what extent environmental problems influence their daily lives. The analysis revealed that the majority (59.7\%) of students perceived environmental problems as influencing their daily lives to a small extent. Only $4.4 \%$ of students thought that environmental problems greatly influenced their lives, while $12.4 \%$ thought that they did not at all.

When comparing the perceptual share, students in Lithuania perceived environmental issues as having the most influence on their daily lives (Table 1). In Finland, students perceived less influence from environmental issues on their daily lives $(\chi 2=$ 79.60; df =6; $\mathrm{p}<0.000)$.

Table 1

Students' Perceptions of the Influence of Environmental Problems on Their Daily Lives $(\mathrm{N}=429)$

\begin{tabular}{|c|c|c|c|c|c|c|c|c|c|}
\hline & & \multicolumn{2}{|c|}{ Finland } & \multicolumn{2}{|c|}{ Lithuania } & \multicolumn{2}{|c|}{ Sweden } & \multicolumn{2}{|c|}{ All } \\
\hline & & Number & $\%$ & Number & $\%$ & Number & $\%$ & Number & $\%$ \\
\hline \multirow{4}{*}{$\begin{array}{l}\text { To what extent do } \\
\text { environmental } \\
\text { problems influence } \\
\text { your daily life? }\end{array}$} & Very much & 6 & 2.0 & 6 & 10.2 & 7 & 11.1 & 19 & 4.4 \\
\hline & A lot & 48 & 15.6 & 36 & 61.0 & 17 & 27.0 & 101 & 23.5 \\
\hline & A little & 209 & 68.1 & 15 & 25.4 & 32 & 50.8 & 256 & 59.7 \\
\hline & Not at all & 44 & 14.3 & 2 & 3.4 & 7 & 11.1 & 53 & 12.4 \\
\hline
\end{tabular}

In written explanations of the influence of environmental issues on their daily life, 11 argumentation categories were found (Table 2). Seven of the categories refer to some influence, and 4 to no influence.

Higher education students mostly argued that environmental problems are present in the actions of daily life ( 69 descriptions). Many students stated that they recycle and buy environmentally friendly products and food. Students also reasoned that influence from environmental problems, particularly pollution, global warming and traffic, can be seen in their choices in daily life (57 descriptions). Many students perceived the existence of environmental problems but not as close to them or visible in their daily lives. A few felt global concern and tried to act for the environment. 
Table 2

Higher Education Students' Arguments Related to the Influence of Environmental Problems in Their Daily Lives

\begin{tabular}{ccc}
\hline Category & $\begin{array}{c}\text { Number of } \\
\text { mentions }\end{array}$ & Examples \\
\hline 1 & 2 & 3
\end{tabular}

They are present $69 \quad$ I live my life whether environmental problems exist or not, in my actions in but I try to do my part, for example, by recycling.

daily life. I do not experience that, for example, global warming, reduction in biodiversity or pollution of water, can be seen in my daily life, other than through media. In a small town, the air feels clean to breathe. I, however, take environmental issues into account in my consumption choices: I recycle, prefer public transport and prepare vegetable food. That's why my answer is a little.

They influence or $57 \quad$ Pollution of middle-sized towns. The impact of global can be seen in warming. Fear of future.

daily life.

The only environmental problems which I perceive to influence my daily life are man-made. These are my hometown's traffic jams on the way to work and the light pollution of the town.

\begin{tabular}{|c|c|c|}
\hline $\begin{array}{l}\text { They can be seen } \\
\text { in nature or the } \\
\text { environment. }\end{array}$ & 37 & $\begin{array}{l}\text { I move a lot in nature near town where the influences of the } \\
\text { closeness of settlement are noticeable. It is difficult to find an } \\
\text { environment which is in a natural state. Traffic pollution and } \\
\text { litter and waste in the environment influence aesthetics. }\end{array}$ \\
\hline $\begin{array}{l}\text { They influence } \\
\text { my thoughts but } \\
\text { not actions. }\end{array}$ & 32 & $\begin{array}{l}\text { I think about them every day, but there exists no personal harm. } \\
\text { I do not experience that environmental problems influence } \\
\text { my daily life at the concrete level but at the level of thoughts. }\end{array}$ \\
\hline Global viewpoint & 19 & $\begin{array}{l}\text { I strive in all my actions to take into account my and my } \\
\text { family's influence on local and global environmental problems. } \\
\text { I believe that the insufficiency of resources and energy will } \\
\text { lead to significant changes and revolution in my lifetime. }\end{array}$ \\
\hline $\begin{array}{l}\text { Expression of } \\
\text { feelings }\end{array}$ & 12 & $\begin{array}{l}\text { I feel guilty because of driving. } \\
\text { They do not have any connection to daily life, but sometimes, } \\
\text { I feel distressed about all problems in the world. }\end{array}$ \\
\hline Influence on work & 4 & $\begin{array}{l}\text { In my work, environmental issues have significant influence. } \\
\text { In production, law-based environmental issues and other } \\
\text { related issue, they are very essential. }\end{array}$ \\
\hline Total (influential) & 230 & \\
\hline $\begin{array}{l}\text { They can't be seen } \\
\text { in daily life. }\end{array}$ & 65 & $\begin{array}{l}\text { In town, for example, the function of electricity and food } \\
\text { services and environmental problems, can be invisible. } \\
\text { They are not visible in daily life: one lives in blocks of flats, } \\
\text { recycles, lives in one's family and circle of acquaintances. }\end{array}$ \\
\hline $\begin{array}{l}\text { They do not } \\
\text { disturb daily life. }\end{array}$ & 42 & $\begin{array}{l}\text { I have not noticed that pollution, global warming or other } \\
\text { issues influence my daily life. } \\
\text { Environmental problems are big things, and much smaller } \\
\text { issues influence daily life. In a welfare state, things are so } \\
\text { good that one can forgot everything, if one wants. The other } \\
\text { thing is if one decides to think about the issues and influence } \\
\text { them. But they are easily forgotten in one's own life's squiggles. }\end{array}$ \\
\hline
\end{tabular}


Sequel to Table 2

\begin{tabular}{lcl}
\hline \multicolumn{1}{c}{1} & 2 & \multicolumn{1}{c}{3} \\
\hline $\begin{array}{l}\text { No environmental } \\
\text { problems exist. }\end{array}$ & 38 & $\begin{array}{l}\text { In Finland, there exist no large environmental problems. } \\
\text { In Finland, environmental problems do not influence daily } \\
\text { life because here, nature and products are clean and safe due } \\
\text { to the strictness of legislation and the sparse population. } \\
\text { There is no need to take care of own safety at a direct level. } \\
\text { I have not noticed any environmental problems in my sur- } \\
\text { roundings. }\end{array}$ \\
& $9 \begin{array}{l}\text { In producing waste, I think where waste goes and could I } \\
\text { promote the reuse? But for example in the shop, I do not } \\
\text { think of the ecologicality of products but make price-quality } \\
\text { comparison. }\end{array}$ \\
\hline
\end{tabular}

Total (not

154

influential)

Next, students were asked to rank, which environmental issues were the most serious. Students' rankings were compared through the mean value. Students perceived clean water for everyone, followed by ocean and air pollution, as the most serious issues, as shown in Table 3. The next issues in ranking were decreased biological diversity and global warming/climate change; however, their means were very near the preceding ones.

Table 3

Seriousness of the Environmental Issues from Students' Perspective (scale: 1 = not at all significant, 2 = least serious, 3 = less serious, 4 = serious)

\begin{tabular}{lccc}
\hline \multicolumn{1}{c}{ Environmental issue } & $\mathrm{N}$ & Mean & Std. deviation \\
\hline Clean water for everyone & 390 & 3.73 & 0.632 \\
\hline Ocean pollution & 395 & 3.71 & 0.576 \\
\hline Air pollution (the impacts on land, water and life) & 393 & 3.69 & 0.558 \\
\hline Decreased biological diversity (animals/plants) & 392 & 3.63 & 0.623 \\
\hline Global warming/climate change & 394 & 3.62 & 0.707 \\
\hline Future energy supply & 379 & 3.60 & 0.681 \\
\hline Ozone layer depletion & 394 & 3.57 & 0.714 \\
\hline Overconsumption & 383 & 3.55 & 0.736 \\
\hline Poverty & 394 & 3.54 & 0.784 \\
\hline Human population growth & 386 & 3.51 & 0.722 \\
\hline Food production issues & 388 & 3.49 & 0.762 \\
\hline Nuclear power and nuclear waste issues & 393 & 3.47 & 0.842 \\
\hline Deforestation/desert expansion & 377 & 3.38 & 0.790 \\
\hline Floods/drought & 403 & 3.37 & 0.811 \\
\hline Chemicalization/toxification & 366 & 3.37 & 0.753 \\
\hline Human diseases (e.g. malaria) & 391 & 3.24 & 0.840 \\
\hline Noise pollution & 400 & 2.97 & 0.858 \\
\hline Acid rain & 304 & 2.86 & 0.903 \\
\hline
\end{tabular}

The least serious issue according to the students was acid rain. It must be noted that the difference in mean between the most and least serious issues was less than 1 . 
Other issues which students mentioned were increasing inequality, destruction of the Baltic Sea, fear of others, gene modification in food production, lack of recycling and war.

Students were asked about their opinions for solving environmental problems and the role of the media in informing the public about environmental issues (see Appendix 1). The division of the responses is shown in Figure 1.

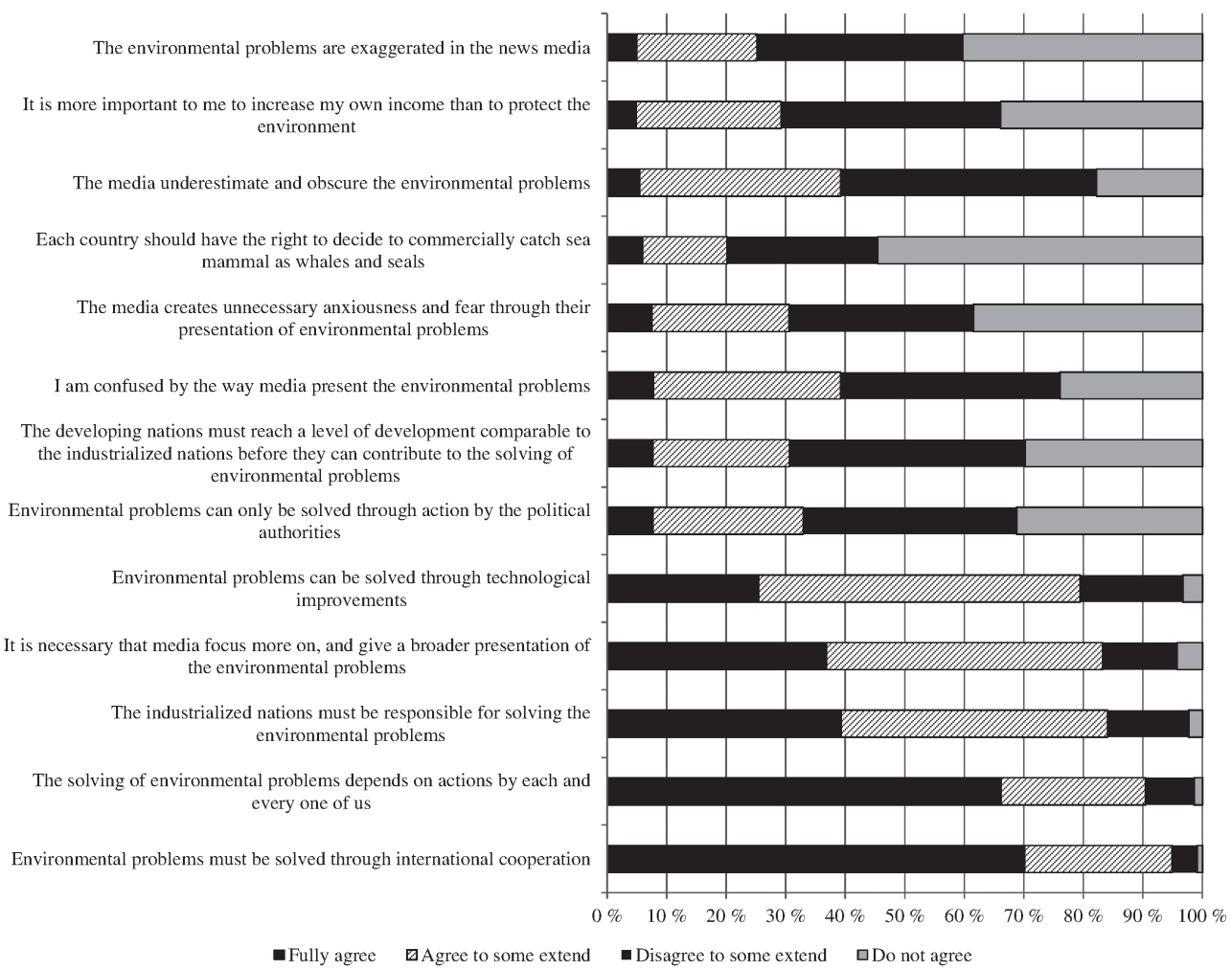

Figure 1. Students' perceptions of environmental problems

Students mostly agreed that environmental problems must be solved through international co-operation. Solving environmental problems was perceived as depending on actions by every person. Participants also perceived industrialised nations as responsible for solving environmental problems. They trusted very little in the ability of technological improvements or political authorities to solve environmental problems.

The media's role related to environmental problems was perceived to be that of an important presenter of environmental problems. Students held the opinion that, to some extent, the media exaggerate environmental problems but do not create unnecessary anxiety and fear through their presentation. Students were confused about the way media present environmental problems.

Finally, students were asked for their opinion of one environmental issue in particular: the greenhouse effect. To illustrate students' understanding of greenhouse effect, the percentages of the mode is shown in Table 4. 

Christel Persson, Rytis Vilkonis

Table 4

Students' Agreement with Statements About the Greenhouse effect $(1=$ disagree, $4=$ agree)

\begin{tabular}{lccc}
\hline \multicolumn{1}{c}{ Statement } & $\begin{array}{c}\text { Mode } \\
(\% \text { of answers })\end{array}$ & Mean & $\begin{array}{c}\text { Standard } \\
\text { Deviation }\end{array}$ \\
\hline The greenhouse effect is necessary for life on Earth. & $4(41 \%)$ & 2.79 & 1.19 \\
\hline $\begin{array}{l}\text { Increased burning of coal, gas, and oil increases the } \\
\text { greenhouse effect. }\end{array}$ & $4(67 \%)$ & 3.56 & 0.72 \\
\hline $\begin{array}{l}\text { Carbon dioxide }\left(\mathrm{CO}_{2}\right) \text {, water vapour and methane } \\
\left(\mathrm{CH}_{4}\right) \text { are the most important gases that cause the } \\
\text { greenhouse effect. }\end{array}$ & $4(46 \%)$ & 3.22 & 0.87 \\
$\begin{array}{l}\text { The greenhouse effect protects against UV radiation } \\
\text { from the sun. }\end{array}$ & $1(56 \%)$ & 1.78 & 1.04 \\
$\begin{array}{l}\text { The greenhouse effect is caused by ozone gas }\left(\mathrm{O}_{3}\right) \\
\text { in the ozone layer. }\end{array}$ & $1(66 \%)$ & 2.11 & 1.01 \\
\hline $\begin{array}{l}\text { The greenhouse effect decreases the temperature } \\
\text { on Earth. }\end{array}$ & $1(35 \%)$ & 1.78 & 1.04 \\
$\begin{array}{l}\text { Chlorofluorocarbon }(\mathrm{CFCs}) \text { gas in spray cans and } \\
\text { refrigerators might destroy the greenhouse effect. }\end{array}$ & $4(30 \%)$ & 2.60 & 1.17 \\
\hline
\end{tabular}

Surprisingly, less than half of students understood that the greenhouse effect is necessary for life on the Earth and only $35 \%$ knew that the greenhouse effect does not decrease the temperature on Earth. About half the students did not agree that greenhouse effect protects against UV radiation from the Sun. Students understood well the cause of greenhouse effect, and that higher carbon dioxide $\left(\mathrm{CO}_{2}\right)$, water vapour, methane $\left(\mathrm{CH}_{4}\right)$, ozone and burning of coal and oil increase the greenhouse effect, and one-third of the students understood that chlorofluorocarbons (CFCs) might destroy the greenhouse effect.

In participants' statements about the greenhouse effect, the perception that $\mathrm{CO}_{2}$, water vapour and $\mathrm{CH}_{4}$ are the most important gases that cause the greenhouse effect was associated with overconsumption $(r=0.163, \mathrm{p}<0.01)$. The relation of increased burning of coal, gas and oil to an increased greenhouse effect was associated with the future energy supply $(\mathrm{r}<0.199, \mathrm{p}<0.01)$ and overconsumption $(\mathrm{r}=0.213, \mathrm{p}<0.01)$. Students perceived that greenhouse gases as due to overconsumption and cause global warming. Future energy supply was perceived as a problem if the use of fossil fuels increases, while overconsumption will cause increased use of fossil fuels.

Students' statements about environmental problems and perceptions of the seriousness of environmental issues had the following correlations. The belief that environmental problems can be solved only through action by political authorities was associated with air pollution (and the impacts on land, water and life) $(r=-0.146, p<0.01)$. The view that solving environmental problems depends on actions by all people was associated with global warming/climate change $(\mathrm{r}=0.204, \mathrm{p}<0.01)$ and nuclear power and nuclear waste issues $(r=0.243, p<0.01)$. Students held the opinion that the authorities are responsible for solving air pollution problems, but individuals' actions might help to solve global warming and nuclear power issues. The belief that industrialised nations are responsible for solving environmental problems was correlated with future energy supply $(\mathrm{r}=0.164, \mathrm{p}<0.01)$ and air pollution (and the impacts on land, water and life) $(\mathrm{r}=0.149, \mathrm{p}<0.01)$. Students perceived industrialised nations as having an important role in solving energy and air pollution problems. 
Related to the media's role in environmental issues, students perceived the media as addressing climate change the most and acid rain the least, as seen in Figure 2. The next most addressed issues in students' opinion were ozone layer depletion, floods/ drought, poverty, future energy supply and nuclear power and waste issues.

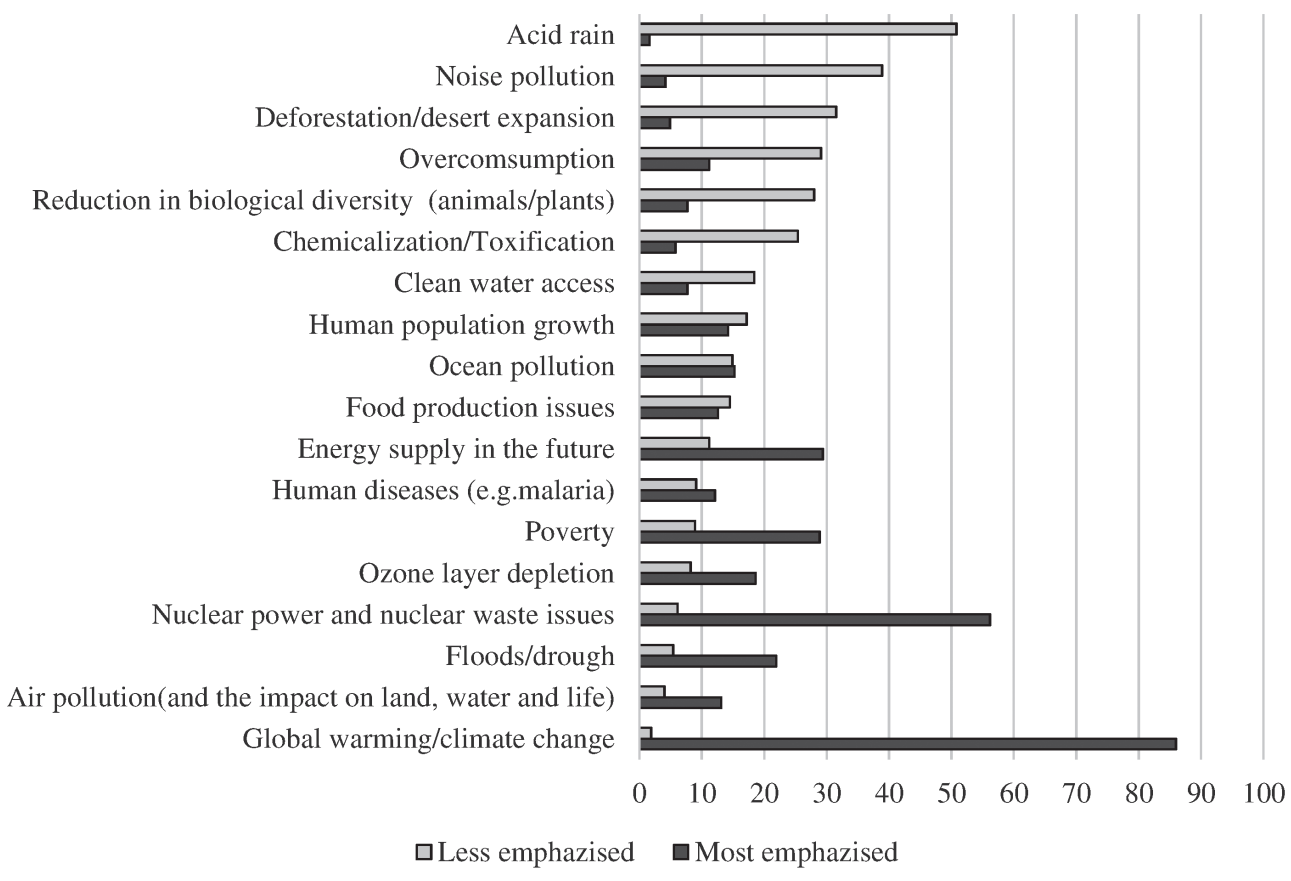

Figure 2. The most and the least emphasised environmental issues (in percentages) in the media according to students

When comparing the seriousness of environmental issues and the media emphasis on them as perceived by students, it was noted that the more serious an issue was perceived as, the less the media were perceived as creating anxiety and fear (Table 5).

Correspondingly, the more serious the environmental issues were considered, the more the media were perceived to underestimate and obscure the problem and the more necessary it was for the media to focus more on and give a broader presentation of the problem.

Students who perceived the media as underestimating and obscuring the following environmental problems considered these problems to be serious: ocean pollution $(\mathrm{r}=0.104, \mathrm{p}<0.05)$, reduced biological diversity $(\mathrm{r}=0.193, \mathrm{p}<0.01)$ and global warming $(\mathrm{r}=0.179, \mathrm{p}<0.01)$. Similarly, students who perceived that it was necessary that media focus more on and give a broader presentation of environmental problems considered the following environmental problems to be serious: ocean pollution $(r=0.166, p<0.01)$, air pollution $(\mathrm{r}=0.192, \mathrm{p}<0.01)$, reduced biological diversity $(\mathrm{r}=0.177, \mathrm{p}<0.01)$, global warming $(r=0.232, p<0.01) ; 0.131, p<0.05)$ and future energy supply $(0.130 . p<0.05)$. The more students considered environmental problems to be serious, the less the media were seen to create unnecessary anxiety and fear through their presentation of environmental problems (the five correlations were negative). 
Table 5

Seriousness of Environmental Issues Versus Emphasis on Environmental Problems in the Media

\begin{tabular}{lccc}
\hline $\begin{array}{c}\text { Spearman correlations } \\
\text { (perceived seriousness } \\
* \text { of media presentation) }\end{array}$ & $\begin{array}{c}\text { The media creates } \\
\text { unnecessary anxiety } \\
\text { and fear through their } \\
\text { presentation of envi- } \\
\text { ronmental problems. }\end{array}$ & $\begin{array}{c}\text { The media } \\
\text { underestimate } \\
\text { and obscure } \\
\text { environmental } \\
\text { problems. }\end{array}$ & $\begin{array}{c}\text { It is necessary that } \\
\text { media focus more on } \\
\text { and give a broader } \\
\text { presentation of envi- } \\
\text { ronmental problems. }\end{array}$ \\
\hline Ocean pollution & $-0.197^{* *}$ & $0.104^{*}$ & $0.166^{* *}$ \\
\hline $\begin{array}{l}\text { Air pollution (and the } \\
\text { impacts on land, water and } \\
\text { life) }\end{array}$ & $-0.213^{* *}$ & & $0.192^{* *}$ \\
\hline $\begin{array}{l}\text { Reduced biological } \\
\text { diversity (animals/plants) }\end{array}$ & $-0.233^{* *}$ & $0.193^{* *}$ & $0.177^{* *}$ \\
\hline $\begin{array}{l}\text { Global warming/climate } \\
\text { change }\end{array}$ & $-0.257^{* *}$ & $0.179 * *$ & $0.232^{* *}$ \\
\hline Energy supply in the future & $-0.213^{* *}$ & & $0.130^{*}$ \\
\hline
\end{tabular}

Note: Correlations are significant at $* \mathrm{p}<0.05$ and $* \mathrm{p}<0.01$.

\section{Discussion}

The majority of Finnish and Swedish students perceived environmental problems to have little influence on their daily lives contrary to the results of the Eurobarometer (TNS Opinion \& Social, 2011). Lithuanian students perceived the influence as highest, which, when comparing the country results, is in line with the Eurobarometer survey (TNS Opinion \& Social, 2011). In Finland, students perceived less influence from environmental problems on their daily lives. This finding is somewhat surprising; students in this study were in higher education and so could be expected to be aware of environmental problems, to participate in solving them and be active in deciding or teaching about environmental issues.

Higher education students perceived clean water, ocean and air pollution, reduced biodiversity, global warming and future energy production as the most serious environmental problems, similar to the concerns of European residents which were related to the direct impact of human activity on the environment at a global level (TNS Opinion \& Social, 2011). The findings in this study are also similar to those from a previous study among Finnish university students, in which climate change and the lack of clean water were found to be the most important environmental problems (Kukkonen et al., 2012). In addition to these global issues, students in this study mentioned local issues which were discussed in the media during the data collection period, such as the destruction of the Baltic Sea, emissions in the Gulf of Finland, transport in the Baltic See, and air pollution.

In conclusion, higher education students reported perceiving less influence from environmental problems in daily life than in earlier studies, but their perceptions of serious environmental issues were similar to those in earlier studies, and contemporary local environmental issues covered by media were also pointed out (c.f. Gooch, 1995; Holbert et al., 2003; Riffe et al., 2007; Riffe \& Hrach, 2009; Smith \& Joffe, 2012; Sarrina Li, 2014). Climate change was not perceived as the most serious issue, even 
though it has dominated environmental news in recent years (Dispensa \& Brulle, 2003; Antilla, 2005; Boykoff \& Boykoff, 2007; Petersen, 2007; Gavin, 2009; Boykoff, 2009; Speck, 2010; Young \& Dugas, 2011; Lyytimäki \& Tapio, 2009; Lyytimäki, 2011).

Higher education students mostly agreed that environmental problems must be solved through international co-operation but also perceived the solutions as dependent on actions by everyone, similar to respondents in the Eurobarometer (TNS Opinion \& Social, 2011). Students also perceived industrialised nations as responsible for solving environmental problems, such as big polluters, consistent with the Eurobarometer results (TNS Opinion \& Social, 2011). Students did not trust that either technological improvements or political authorities could solve environmental problems contrary to findings about the perceptions of Europeans in general (TNS Opinion \& Social, 2011). A majority believed that decisions about environmental protection should be made at an EU-wide level or by national governments. This study reflects the complex and often contradictory nature of the public's common-sense thinking in relation to risk issues (cf., Smith \& Joffe, 2012).

The media were perceived to have an important role as a presenter of environmental problems (c.f., Keinonen et al., 2014), but according to the students, the media, to some extent, exaggerate environmental problems, although they do not create unnecessary fear or confusion related to environmental problems. This view is in line with the perceptions of most Europeans who were well informed about environmental issues (TNS Opinion \& Social, 2011).

Higher education students understood that the greenhouse effect is necessary for life on Earth, and some students perceived the greenhouse effect as decreasing temperatures on Earth. Students well understood the causes of the greenhouse effect, namely that $\mathrm{CO}_{2}$, water vapour, $\mathrm{CH}_{4}$, ozone and the burning of coal and oil increase the greenhouse effect. Half of the students understood that CFCs could destroy the greenhouse effect. In short, higher education students, mostly prospective teachers, were as aware of the greenhouse effect as different groups in society (c.f., Anderson \& Wallin, 2000; Boyes \& Stanisstreet, 1993; Shepardson et al., 2011; TNS Opinion \& Social, 2011; Smith \& Joffe, 2012; Feldman et al., 2010; Wachholz et al., 2014). However, it could be expected that higher education students should understand global warming better than citizens in general or students in lower-level schools.

Higher education students perceived the media as emphasising climate change, ozone layer depletion, floods/drought, poverty, future energy supply and nuclear power and waste issues. Among these issues, only climate change was frequently discussed in the media during the data collection period. The more seriously students perceived a problem, the exaggerated they perceived its coverage in the media. Higher education students did not perceive the media as exaggerating many of the environmental problems they perceived as serious. Similarly, Kellstedt et al. (2008) found that available information was positively associated with concern for all environmental issues. Students perceived the media as underestimating and obscuring serious environmental problems, such as global warming and decreased biological diversity. 


\section{Conclusions}

Higher education students including teacher students in three Nordic-Baltic countries perceived a global problem - the lack of clean water-as the most serious environmental problem. Students also mentioned local issues which have been discussed in the media, such as the destruction of the Baltic Sea. Climate change was not perceived as the most serious issue, even though it dominated the environmental news which students consumed. The media have influenced students' perceptions of environmental issues. When students perceived a problem as serious, they also perceived the information in media about it appropriate. The role of the media was perceived as an important presenter of environmental problems: the media, to some extent, exaggerate environmental problems but do not create unnecessary fear or confusion. Students perceived that the media as underestimating and obscuring some environmental problems, such as biological diversity and global warming.

Finnish and Swedish higher-education students perceived environmental problems as influencing their daily lives only a little, while Lithuanian students perceived a stronger influence. This result might be due to differences in actual environmental conditions in these countries. As well, differences in media coverage might create variations in perceptions. Students believed that environmental problems must be solved at both the global and the local level, but they did not put much trust in the ability of technological improvements to solve the environmental problems. Technology was not seen as the only solution; people must change their behaviour, too. Students were well aware of the greenhouse effect, which will help them in environment-related decision making in the future.

This study offers some insights into higher education students' perceptions of the media's role in environmental issues. Differences in perceptions of seriousness among the students in three countries might be due, for example, to different environmental problems or the presentation of different environmental information in the media or school education. Activities supporting critical thinking in consuming media and disseminating knowledge about environmental issues are also needed in higher education. Students pointed to the need for a discussion of ethical issues related to environmental issues in higher education. For example, there is the need to discuss the greenhouse effect as some students expressed misunderstandings about it. Many students perceived environmental issues as not influencing their daily lives, which could lead to careless behaviour. To avoid this, environmental friendly behaviour should be discussed more in higher education.

Students receive knowledge through media but based on this study it can be concluded that media in some extend also influences students' perceptions, attitudes and concerns which are precursors for behaviour and decision-making. Therefore, it is strongly recommended that the role of media should be included in the models concerning the complex relationships between perceptions, attitudes, concerns and behaviour and participation.

This study has some limitations. One, the sample size of students from various countries and study programmes was different, but statistically significant differences were found. More students from all study programmes should be recruited for future studies. Two, the mapping of media coverage provided only an overview of the issues discussed in media and should be done in more detail in future research. 


\section{References}

Andersson, B., \& Wallin, A. (2000). Students' understanding of the greenhouse effect, the societal consequences of reducing $\mathrm{CO} 2$ emissions and the problem of ozone layer depletion. Journal of Research in Science Teaching, 37(10), 1096-1111.

Antilla, L. (2005). Climate of scepticism: US newspaper coverage of the science of climate change. Global Environmental Change, 15, 338-352.

Bogner, F.X., \& Wilhelm, M.G. (1996). Environmental perspectives of pupils: The development of an attitude and behaviour scale. The Environmentalist, 16, 95110.

Bogner, F.X., \& Wiseman, M. (2002). Environmental perception: Factor profiles of extreme groups. European Psychologist, 7, 225-237.

Boykoff, M. T. (2009). We speak for the trees: Media reporting on the environment. Annual Review of Environment and Resources, 34, 431-57.

Boykoff, M. T., \& Boykoff, J. M. (2007). Climate change and journalistic norms: A case study of US mass-media coverage. Geoforum, 38, 1190-1204.

Campbell Bradley, J., Waliczek, T.M., \& Zajicek, J.M. (1999). Relationship between environmental knowledge and environmental attitude of High school students. The Journal of Environmental Education, 30(3), 17-21.

Dispensa, J. M., \& Brulle, R. J. (2003). Media's social construction of environmental issues: Focus on global warming-a comparative study. International Journal of Sociology and Social Policy, 23(10), 74-105.

Dunlap, R.E. \& Van Liere, K.D. (1978). The “new environmental paradigm”: A proposed measuring instrument and preliminary results. Journal of Environmental Education, 9, 10-19.

Esa, N. (2009). Environmental knowledge, attitude and practices of student teachers. International Research in Geographical and Environmental Education, 19(1), 39_ 50 .

Feldman, L., Nisbet, M., Leiserowitz, \& Mailbach, E. (2010). The climate generation? Survey analysis of the perceptions and beliefs of young Americans. Yale Project on Climate Change and Center for Climate Change Communication. Yale University and George Mason University.

Frank, A. K. (2014). Writing about sustainability science for the media: How to be both true-to-fact and tell a good story. Applied Environmental Education \& Communication, 13(3), 203-211.

Freedman, E. (2011). Environmental journalism in Kyrgyzstan and Kazakhstan: Reporting scarce amid environmental and media problems. Applied Environmental Education \& Communication, 10(2), 126-134.

Gavin, N. T. (2011). Addressing climate change: a media perspective. Environmental Politics, 18(5), 765-780.

Gooch, G. D. (1995). The Baltic press and the environment: A study of the coverage of environmental problems in Estonian and Latvian newspapers 1992-1993. Geoforum, 26(4), 429-443.

Holbert, R. L., Kwak, N., \& Shah, D.V. (2003). Environmental concern, patterns of television viewing, and pro-environmental behaviors: Integrating models of media consumption and effects. Journal of Broadcasting \& Electronic Media, 47(2), 177196. 
Iliško, D., Skrinda, A., \& Mičule, I. (2014). Envisioning the future: Bachelor's and Master's degree students' perspectives. Journal of Teacher Education for Sustainability, 16(2), 88-102.

Johnson, B. \& Manoli, C.C. (2011). The 2-MEV Scale in the United States: A Measure of Children's Environmental Attitudes Based on the Theory of Ecological Attitude. The Journal of Environmental Education, 42(2), 84-97.

Keinonen, T., Yli-Panula, E., Svens, M., Vilkonis, R., Persson, C., \& Palmberg, I. (2014). Environmental issues in media-students' perceptions in three Nordic-Baltic countries. Journal of Teacher Education for Sustainability, 16(1), 32-53.

Kellstedt, P. M., Zahran, S., \& Vedlitz, A. (2008). Personal efficacy, the information environment, and attitudes toward global warming and climate change in the United States. Risk Analysis, 28(1), 113-126.

Kukkonen, J., Kärkkäinen, S., \& Keinonen, T. (2012). University students' information sources of education for sustainable development issues and their perceptions of environmental problems. Problems of Education in the 21st Century, 39, 94-105.

Lyytimäki, J. (2011). Mainstreaming climate policy: The role of media coverage in Finland. Mitigation and Adaptation Strategies for Global Change, 16(6), 649661.

Lyytimäki, J., \& Tapio, P. (2009). Climate change as reported in the press of Finland: From screaming headlines to penetrating background noise. International Journal of Environmental Studies, 66(6), 723-735.

Petersen, L. K. (2007). Changing public discourse on the environment: Danish media coverage of the Rio and Johannesburg UN summits. Environmental Politics, 16(2), 206-230.

Riffe, D., \& Hrach, T. (2009). Study explores audience's views on environmental news. Newspaper Research Journal, 30(3), 8-25.

Riffe, D., Lacy, S., \& Reimold, D. (2007). Papers lead TV in covering complex environmental issues. Newspaper Research Journal, 28, 77-87.

Salite, I. \& Klepere, R. (2003). Biotism as a ground for the education of refection in teacher education. Journal of Teacher Education and Training, 3, 44-58.

Sarrina Li, S. C. (2014). Fear appeals and college students' attitudes and behavioral intentions toward global warming. The Journal of Environmental Education, 45(4), 243-257.

Schultz, P. W. (2000). Empathizing with nature: The effects of perspective taking on concern for environmental issues. Journal of Social Issues, 56(3), 391-406.

Shanahan, J., Morgan, M., \& Stenbjerre, M. (1997). Green or brown? Television and the cultivation of environmental concern. Journal of Broadcasting \& Electronic Media, 41(3), 305-323.

Skamp, K., Boyes, E., \& Stanisstreet, M. (2004). Students' ideas and attitudes about air quality. Research in Science Education, 34(3), 313-342.

Smith, N., \& Joffe, H. (2012). How the public engages with global warming: A social representations approach. Public Understanding of Science, 22(1), 16-32.

Speck, D.L. (2010). A hot topic? Climate change mitigation policies, politics, and the media in Australia. Human Ecology Review, 17(2), 125-133.

TNS Opinion \& Social. (2011). Special Eurobarometer 365. Attitudes of European citizens towards the environment. Retrieved March 3, 2013 from http://ec.europa.eu/ public_opinion/index_en.htm 
Young, N., \& Dugas, E. (2011). Representations of climate change in Canadian national print media: The banalization of global warming. Canadian Review of Sociology, 48(1), 1-22.

Wachholz, S., Artz, N., \& Chene, D. (2012). Warming to the idea: University students' knowledge and attitudes about climate change. International Journal of Sustainability in Higher Education, 15(2), 128-141.

Correspondence concerning this article should be addressed to Professor Tuula Keinonen, University of Eastern Finland, School of Educational Science and Teacher Education, P.O. Box 111, 80101 Joensuu, Finland. Email: Tuula.Keinonen@uef.fi

\section{Appendix 1}

Six Questions Analysed and the Multiple-Choice Responses

\begin{tabular}{|c|c|c|}
\hline No. & Question & Response form and alternatives \\
\hline 1 & 2 & 3 \\
\hline 1 & $\begin{array}{l}\text { To what extent do } \\
\text { environmental issues } \\
\text { influence your daily } \\
\text { life? }\end{array}$ & $\begin{array}{l}\text { Measured on a 4-point scale, where } 1=\text { very much and } 4= \\
\text { not at all; open-ended questions to capture students' reasoning }\end{array}$ \\
\hline 2 & $\begin{array}{l}\text { Which environmental } \\
\text { issues do you consider } \\
\text { the most serious today? }\end{array}$ & $\begin{array}{l}\text { The given choices were acid rain, ozone layer depletion, noise } \\
\text { pollution, global warming/climate change, nuclear power and } \\
\text { nuclear waste issues, ocean pollution, reduction in biological } \\
\text { diversity (animals/plants), air pollution (and the impacts on } \\
\text { land, water and life), deforestation/desert expansion, floods/ } \\
\text { drought, poverty, future energy supply, clean water access, } \\
\text { human population growth, food production issues, human } \\
\text { diseases (e.g. malaria), overconsumption, chemicalization/ } \\
\text { toxification, and other (please specify). Scale: } 1 \text { = not at all } \\
\text { significant, } 4 \text { = significant }\end{array}$ \\
\hline 3 & $\begin{array}{l}\text { Which three environ- } \\
\text { mental issues are, in } \\
\text { your opinion, most } \\
\text { emphasized by the } \\
\text { media? }\end{array}$ & $\begin{array}{l}\text { The given choices were acid rain, ozone layer depletion, noise } \\
\text { pollution, global warming/climate change, nuclear power and } \\
\text { nuclear waste issues, ocean pollution, reduction in biological } \\
\text { diversity (animals/plants), air pollution (and the impacts on } \\
\text { land, water and life), deforestation/desert expansion, floods/ } \\
\text { drought, poverty, future energy supply, clean water access, } \\
\text { human population growth, food production issues, human } \\
\text { diseases (e.g. malaria), overconsumption, chemicalization/ } \\
\text { toxification, and other (please specify) }\end{array}$ \\
\hline
\end{tabular}

$4 \quad$ Which three environ- The given alternatives were the same as in question 2 mental issues are, in your opinion, least emphasized by the media?

$5 \quad$ With which of the following statements do you agree/disagree?

Environmental problems can be solved through technological improvements. Environmental problems can be solved only through action by political authorities. Solving environmental problems depends on actions by each and every one of us. 
Sequel to Appendix 1

\begin{tabular}{ll}
\hline 1 & \multicolumn{1}{c}{3} \\
\hline & Environmental problems must be solved through international \\
co-operation. Industrialised nations must be responsible for \\
solving environmental problems. \\
Developing nations must reach a level of development com- \\
parable to industrialised nations before they can contribute to \\
solving environmental problems. \\
Industrialised countries should solve environmental problems. \\
It is more important to me to increase my own income than \\
to protect the environment. \\
Environmental problems are exaggerated in the news media. \\
The media create unnecessary anxiety and fear through their \\
presentation of environmental problems. \\
The media underestimate and obscure environmental problems. \\
I am confused by the way media present environmental \\
problems. \\
It is necessary that media focus more on and give a broader \\
presentation of environmental problems. \\
Each country should have the right to decide on commercial \\
catches of sea mammals, such as whales and seals. \\
Scale: 1 = disagree, $4=$ agree \\
\hline The greenhouse effect protects against UV radiation from \\
the sun. \\
The greenhouse effect decreases the temperature on earth. \\
Carbon dioxide (CO2), water vapour and methane (CH4) are \\
the most important gases that cause the greenhouse effect. \\
Chlorofluorocarbon (CFCs) gas in spray cans and refrige- \\
rators might destroy the greenhouse effect. \\
Increased burning of coal, gas and oil increases the green- \\
house effect. \\
disagree? \\
The greenhouse effect is caused by ozone gas (O3) in the \\
Ozone layer. \\
The greenhouse effect is necessary for life on Earth. \\
Scale: 1 = disagree, $4=$ agree \\
\hline
\end{tabular}

